\title{
Edetate Calcium Disodium
}

National Cancer Institute

\section{Source}

National Cancer Institute. Edetate Calcium Disodium. NCI Thesaurus. Code C334.

Contracted name for a salt of ethylenediaminetetraacetate, an agent used as a chelator of lead and some other heavy metals. $\mathrm{C} 10 \mathrm{H} 12 \mathrm{CaN} 2 \mathrm{Na} 2 \mathrm{O} 8$. 